\section{West Germany: eyeball to eyeball over nuclear fuel reprocessing}

NEXT week, critics and supporters of nuclear power will be meeting in Hanover, West Germany to analyse proposals to build a nuclear fuel reprocessing and waste disposal facility at a site $5 \mathrm{~km}$ from the East German border near the village of Gorleben in Lower Saxony. The forum for the analysis is to be a week of public hearings organised by the state government of Lower Saxony.

Twenty-five expert nuclear critics, 20 of them from outside West Germany, will face 25 nuclear supporters in a 'round table' discussion: an audience of 200 will listen in. The ostensible aim of the hearings is to inform the public and to help Ernst Albrecht, premier of the Lower Saxony government, decide whether or not to grant a licence for construction of the facility.

Already there are fears that the hearings will get off to a bad start. Some of the critics are suspicious of the state government's motivation for holding them: they think that pressure from the federal government means that construction of the plant is inevitable. They are also critical of the delay in deciding on a format for the hearings and of the lack of public information on them. Three weeks before them, the names of the 25 pro-nuclear experts had not been released, although the anti-nuclear names had been known for a long time.

Criticism has also been levelled at the way in which the 200 places in the audience have been allocated. Apparently about 100 places are to be taken by state and government authorities, 20 by representatives of the nuclear industry, 30 by the press, only three by members of local environmentalist groups and one by a representative of the district authority. The remainder are for members of parliament of Lower Saxony. With no spare places for interested members of the public and only 30 press places, it is argued, the hearings are not truly public.

The proposal under discussion is for the construction of a plant capable of reprocessing all of West Germany's spent nuclear fuel. It would include spent fuel storage ponds and plants for fabricating mixed oxide fuel, uranium finishing, vitrifying high-level radioactive waste as well as reprocessing 1,400 tonnes of spent fuel per year. Final disposal of all radioactive waste would also be on the site in salt domes a few hundred metres below the surface. The total cost is estimated at DM12,000 million.
The nuclear industry, amongst others, expects the decision reached by the Lower Saxony government over the licensing of the plant to be crucial to the future of nuclear power in West Germany. In the summer of 1977 , the federal government announced that no new reactors could be licensed until the problem of disposing of spent nuclear fuel--Entsorgung-had been solved. Since then, reprocessing has generally been assumed as the only way of satisfying that condition. Unless an alternative can be found (and the nuclear critics hope to show next week that there is one) a veto of the reprocessing plant is expected to mean an end to the expansion of nuclear power in West Germany.

Plans for the proposed facility, or Entsorgungszentrum, were first submitted to the Lower Saxony government in March 1977, by DWK, a company set up by the West German utilities specifically to build it. At the same time, plans for the underground waste storage facility were submitted by the federal Physical-Technical Institute. A 3,000-page safety report, which accompanied the two applications, was examined by the Commission for Reactor Safety and the Commission for Radiological Protection, two advisory bodies to the federal Ministry for the Interior. In October 1977, both bodies published their comments on the safety report saying that they found it reliable and acceptable. The federal government, believing that the disposal of spent nuclear fuel was under control, began to talk about expanding the nuclear programme.

Meanwhile, local people in Gorleben started to protest about the proposal. They felt that the two commissions had been biased in their assessments of the safety report. In addition, DWK had started to try to purchase land from local landowners by offering them a very high price if they sold by a certain date. If they missed the dealing, DWK theatened to start expropriations procedures to procure the land for a much lower price.

To date only $40 \%$ of the land has been sold. Of the remaining $60 \%$, the vast majority is owned by one manCount Bernstorff, a remnant of the German aristocracy and prominent figure in the local landowner association (which has been very active in organising the protest).

At the beginning of 1978, the landowners association began to put pressure on the Lower Saxony govern-

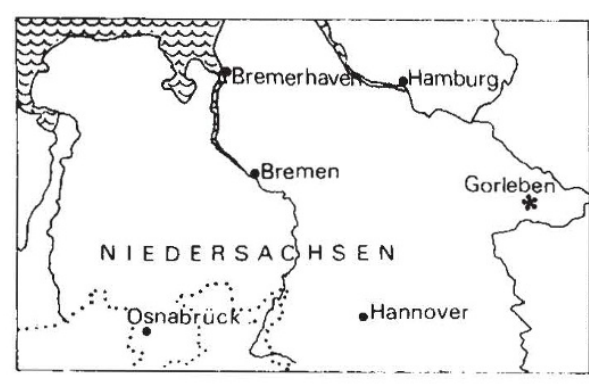

ment to set up a committee of independent nuclear experts to review the proposals. After approaching one or two foreign experts to gauge support for the idea, the association drafted a list of experts it wanted to sit on a review committee. After elections in June of last year, when local environmentalist groups took $18 \%$ of the votes in Gorleben and $3.9 \%$ in the surrounding area, the state government agreed to invite the experts to spend 30 days producing their own report on the proposals and safety report.

In September 1978, 20 expert nuclear critics from France, Norway, Sweden, the UK and the US met in Hanover for the first time. By the beginning of March they had prepared a 2,200-page report and had submitted it to the Lower Saxony Ministry of Social Affairs. The report consists of eight chapters each prepared by different experts. The first chapter is a general introduction, the second discusses routine emission of radiation and radiological protection, the third accidents, the fourth safeguarding of fissile materials, the fifth the technical problems of reprocessing, the sixth waste management, the seventh final disposal and the eighth decommissioning. Among those taking part in the review were Walt Patterson and Amory Lovins of Friends of the Earth, Frank Barnaby of the Stockholm International Peace Research Institute, Paul Sieghart of the International Commission of Jurists and Professor $O$. Lindstrom of the Royal Institute of Technology, Stockholm.

Although the members of the review panel started work last September, they did not receive their contracts until the end of December. Several of them claim that during discussion of the terms of the contract they had requested that the report be published before the public hearings. However, the contracts said that the report had to be withheld from publication until 10 July.

A significant achievement of this action has been to increase dissatisfaction with the way the review and hearings are being run. The state government is committed to take some decision on the future of the reprocessing plant in May or June, before 
the July publication date. Some feel this defeats the object of the review as a public information exercise.

More generally, there are feelings that the government would not seriously contemplate calling a halt to the plant whatever the outcome of the hearings. The formal licensing procedure was begun in 1977, and although it has now almost ground to a halt, it is thought that the Lower Saxony government would be unlikely to stop it abruptly. Even if licensing were now to proceed as fast as possible, it would be 1981 before it were completed. What seems most likely, therefore, is a 'vague' decision.

Whilst the critics and nuclear industry are discussing the Gorleben proposals next week, the people of Gorle- ben, who do not have an invitation to the hearings, will be taking part in a demonstration march from Gorleben to Hanover. The Lower Saxony government is expecting the affair to be violent for it is reported that 100 prisoners have been transferred from local gaols to make way for the recalcitrant villagers.

Judy Redfearn

\section{US panel approves research on in vitro fertilisation}

The US is likely to end a three-year moratorium on research on the in vitro fertilisation of human ova following the conclusions of a federal advisory board that there are no ethical objections to such research being carried out on federal funds.

The ethics advisory board was established last year by $\mathrm{Mr}$ Joseph $\mathrm{A}$. Califano Jr, Secretary of Health Education and Welfare, to advise him on whether work along the lines of the British research workers $\mathrm{Mr}$ Patrick Steptoe and Dr Robert Edwards should be permitted to proceed in the US. On reaching its conclusion, however, the board declined to say whether it felt that such research should in fact receive federal support.

Having heard evidence from scientists, religious leaders, anti-abortion groups, infertile couples and others, the board recommended that the work should be permitted provided that a number of requirements were met. These include:

- that research be aimed primarily at establishing the safety and efficacy of procedures for in vitro fertilisation;
- that no embryo be sustained in laboratory conditions for more than 14 days;

- that both the participants in the research-which would include clinical trials - and the public be informed if there is any evidence that such research is having ill-effects.

Although these provisions, and the decision to recommend that the moratorium be lifted, were agreed unanimously by the 13-member board of lawyers, scientists and others, there was less agreement on the priority which in vitro fertilisation should be given as a research topic.

Several members suggested that it should come low on the national priority list, and one suggested that the government should not fund any such research. Others disagreed, claiming that the research might soon become a "high priority" if there is wide demand from doctors to adopt the new techniques.

The board therefore agreed not to recommend whether HEW should fund such research, accepting that in addition to ethical concerns, this also raised scientific, economic and political considerations.

Funds for 'test-tube baby' research have been held up for more than three years in anticipation of the advisory board's report, although the members of the board were only announced last summer. Congress placed a total ban on all research involving fetuses in 1974, and although this ban was lifted one year later, the position with respect to in vitro fertilisation has remained uncertain.

The only application at present lodged with HEW for carrying out such research is from Dr Pierre Soupart of Vanderbilt University, who has been waiting since 1975 . The ethics board suggests that Dr Soupart's application now be forwarded to the National Institutes of Health for scientific review.

The board also recommended that the secretary of HEW should encourage, and even possibly provide financial support for, the development of a model law outlining the legal status of children born as a result of in vitro fertilisation.

\section{Spanish universities unhappy with new autoinomy law}

SpaIN's universities have long sought autonomy from government controland they should achieve it as one of the first actions of Spain's new government. But it may not prove to be the prize once dreamed of.

The first duty of the new government will be to debate the laws outlined in Spain's new constitution; and one of these is a law granting university autonomy: but was the law wellframed?

Government officials, political parties, and university professors are unanimous in their belief that the universities need rapid attention: they suffer from overcrowding, graduate unemployment, poor teaching, and lack of research. Furthermore the universities do not have the power to distribute their own funds, to select their staff or students, or to organise their own teaching. Every decision has to pass through the central Ministry of Education.

Even before the Constitution was written and approved, the Ministry of Education and Science was preparing a draft of a law for autonomy, anddespite strong criticism-it was forced through the Council of Ministers and entered parliament the day before its dissolution.

The law as it has been published is a long and in certain aspects detailed text. It deals at length with the structure of university management (Senate, Rector, etc.) and with the teaching staff; but it deals only briefly with the administrative staff and research.

Two changes introduced by the new law are financial autonomy, and the separation of academic and economic authorities. The law also allows the existence of private universities, which would interest certain religious societies.

But many points in the law have received criticism from the universitiessuch as the system of selection of teaching staff, which remains almost untouched. For example, an aspirant to full professorship (Catedrático) must spend three years as associate professor (Adjunto), a regulation which bars many non-academic professionals whose expertise might benefit a university.

The law also describes-in detailthe composition of the various university institutions, making it difficult to apply to any new university, while some fundamental problems--such as the role and funding of research, the selection of students, and increases in funding or staff, are left untouched.

The parliament formed after the elections held on 1 March is almost identical to the previous one, and the centrist party will most likely be charged with the task of forming the new government. It will probably back the existing law as created by the Ministry.

In the universities it is hoped that the law may produce some positive changes, but it is regretted that a general debate and a deep rethinking of the function of the universities in Spain has not taken place. If the law is approved as it is, it may be felt by the teaching community as a lost opportunity.

Pedro Puigdoménech 